\title{
Oskar Szwabowski
}

Uniwersytet Szczeciński

\section{Mała wywrotowa polityka}

Książka Jeffreya C. Goldfarba Polityka Rzeczy maŁych. SiŁa BezsilNYCH W MROCZNYCH CZASACH, porusza ważne, współczesne problemy. Kryzys polityki, demokracji, wyłanianie się nowych, sieciowych metod oporu - stanowią obecnie zarówno przedmiot zainteresowań teoretyków, jak i wiążą się z życiem codziennym obywateli na całym globie. Wiele wskazuje, że znajdujemy się w epoce przełomu. Spełniają się słowa Wallerstina, że ludzkość znalazła się w momencie bifurkacji: wyłaniania się radykalnej demokracji i posępnego, faszystowskiego totalitaryzmu. Czas pełzającej rewolucji i bezwzględnej kontrrewolucji wymaga od intelektualisty podjęcia zarówno pracy organizacyjnej, jak i teoretycznej. Goldfarb stara się rozpoznać potencje polityki codzienności, polityki dziejącej się na najniższym poziomie, która to praktyka może stanowić przeciwwagę dla współczesnych totalitaryzmów. W mojej recenzji przede wszystkim rekonstruuję rozumienie polityki rzeczy małych, starając się odpowiedzieć na pytanie, czy teoretyczne propozycje Goldfarba są w stanie sprostać obecnym wyzwaniom. Zastanawiam się, na ile jego rozważania mogą być przydatne w walce emancypacyjnej, a na ile mogą ją zablokować, opóźniać czy korumpować w inny sposób. Analizując książkę Goldfarba odnoszę jego rozważania również do edukacji - jako przestrzeni testu poziomu teoretycznego omawianej myśli. Wydaje mi się, że pomimo inspirujących fragmentów: zwrócenia uwagi na niektóre aspekty, dowartościowanie oddolnej, codziennej sfery działań jako działań politycznych, rozpoznanie fundamentalizmu w sercu oficjalnej demokracji, pozornej oddolności ruchów prawicowych praca Goldfarba musi zostać przezwyciężona. W wielu miejscach autor maskuje problemy, rozmywa je czy proponuje zbyt proste rozwiązania. Zdaje się również powstrzymywać radykalne dążenia, wiążąc nieustannie politykę oddolną z oficjalną. 
David Graeber we wstępie do esejów mających na celu przemyślenie znaczenia rewolucji pisze o mrocznych czasach, jakie nastały dla ruchów społecznych po 11 września. Wojna $z$ terroryzmem stała się narzędziem walki z ruchami antysystemowymi iswobodami obywatelskimi. Dyktatura neoliberalizmu nasilała się proporcjonalnie do wygasania nadziei i punktów oporu. Panowanie systemu opierało się na blokowaniu wszelkich alternatyw, produkowaniu rozpaczy i strachu ${ }^{1}$. 11 września przyczynił się do dalszego upadku demokratycznej wizji i wolnościowych nadziei, wprowadzając cały glob w ramy starcia dwóch nowych totalitaryzmów. Pragnieniem Graebera jest próba przemyślenia możliwości rewolucyjnej, demokratycznej polityki w czasach kryzysu. W mroku poszukuje przebłysków nadziei. Pyta o siłę, jaką mogą dysponować bezsilni. Są to poszukiwania podejmowane przez wielu myślicieli związanych z radykalną, demokratyczną lewicą. Są to również pytania, które zadają sobie „etyczni” liberałowie. Są to pytania, które leżą u podstaw refleksji Jeffreya C. Goldfarba.

Autor wychodzi od diagnozy, że walka z terroryzmem jest odbiciem walki terrorystycznej. Skrajne bieguny okazują się dwiema stronami tej samej monety. Przywołując tezę o tożsamości komunizmu i nazizmu, stwierdza, że po 11 września mamy do czynienia $z$ odrodzeniem totalitaryzmu po obu stronach. Zarówno w projekcie terrorystów jak w projekcie antyterrorystów nie ma miejsca dla demokracji. Próby wyjścia $z$ dramatycznej sytuacji, lokującej nas między „złymi wyborami”, poszukuje autor w specyficznej sferze działania politycznego, które określa mianem „polityki rzeczy małych”. Taka działalność miałaby stanowić sposób walki ze złem, która nie wytwarzałaby innego zła.

Mogłoby się wydawać, że władza należy tylko do wielkich - polityków i korporacji. Zwykli ludzie nie mają wyboru, muszą działać zgodnie z zaleceniami władzy. Formy postępowania są zdeterminowane przez „struktury". Podmioty są jedynie elementami maszyny społecznej, trybikami obracającymi się zgodnie $\mathrm{z}$ „obiektywnymi prawami”. Menedżerowie kontrolują funkcjonowanie, nadają tempo, narzucają cele. Władza zarządców uniemożliwia podejmowanie autonomicznych działań, procesów samowaloryzacji, jakiegokolwiek „robienia swojego”. „Realna władza to władza portfela i prawa. Siła małych rzeczy jest po prostu zbyt słaba, a liczenie na nią - mało rozumne”. Goldfarb nie zgadza się na taką diagnozę. Dowodzi, że "polityka rzeczy małych" stanowi siłę wywrotową, mogącą obracać w ruinę dyktatury.

D. Graeber, Revolutions in Reverse: Essays on Politics, Violence, Art, and Imagination, Minor Compositions, Londyn - Nowy Jork - Port Watson 2011.

2 J. C. Goldfarb. Polityka rzeczy małych. Siła bezsilnych w mrocznych czasach, przekł. U. Lisowska, K. Liszka, A. Orzechowski, DSW, Wrocław 2012, s. 9. 
Czym jest „polityka rzeczy małych”? Nim spróbuję odpowiedzieć na to pytanie warto zwrócić uwagę, że polityka jest ujmowana przez autora w perspektywie zarysowanej przez Arendt. Duch tego, co polityczne rozkwita w utopijnej greckiej polis, którą autorka przywołuje wielokrotnie na stronach swoich książek. Polityka jest przede wszystkim związana z wolnością i dialogiem. W politycznej przestrzeni wielość różnic spotyka się, by wspólnie dyskutować. Dyskusja nie toczy się w przestrzeni zamkniętej, ale wielogłos otwiera świat. Goldfarb podąża tym tropem, dostrzegając to, co polityczne w codziennych spotkaniach, relacjach międzyludzkich, w dyskutowaniu i negocjowaniu znaczeń.

„Gdy ludzie rozmawiają ze sobą, samodzielnie definiując sytuację i rozwijając zdolność do działania w porozumieniu, tworzą tym samym demokratyczną alternatywę dla terroru i hegemonicznej siły”.

Goldfarb zamiast konstruować dokładne definicje podaje przykłady funkcjonowania „polityki rzeczy małych”. Przywołuje obrazy z „totalitarnej przeszłości" - kuchennego stołu, księgarni w mieszkaniu, podziemnego salonu jako przestrzeni rozwoju i praktykowania „polityki rzeczy małych”. W ukrytej sferze prywatnej rozkwitała niewidoczna, podziemna przestrzeń publiczna. Pod maską nałożoną przez totalitaryzm ludzie spotykali się, dyskutowali i wytwarzali tym samym alternatywne społeczeństwo. Według Goldfarba to właśnie ten codzienny, mały wymiar polityki doprowadził i nadał charakter transformacji. Bez minipraktyk oporu zmiana nie byłaby możliwa. „Polityka rzeczy małych” jest dla autora nie tylko alternatywną perspektywą myślenia i praktykowania polityki, która pozwoli wyłonić się porządkowi demokratycznemu, ale również potężną siłą, ważnym czynnikiem zmiany społecznej.

„Polityka rzeczy małych” oznacza tworzenie alternatywnego społeczeństwa w ramach już istniejących struktur. Goldfarb wielokrotnie przytacza wypowiedź Michnika: „działali tak, jak gdyby żyli w wolnym społeczeństwie”. Stanowi ona opis funkcjonowania analizowanej polityki. W ramach codziennych, potocznych wydarzeń, osoby spotykają się i inicjują sytuacje, które nie są zdefiniowane przez panującą ideologię. W ramach tych relacji zawieszają istniejące stosunki. Ruch Społeczeństwa Alternatywnego kierował się podobną logiką. Walka nie odbywa się na poziomie ideologii. Nie przeciwstawia się jednej metanarracji innej metanarracji, czy też jednej ideologii, drugiej, równie totalnej i zniewalającej. Pisząc o opozycji w czasach komunizmu stwierdza: „Ideologii komunistycznych władz nie sprzeciwiają się za pomocą

3 Ibidem, s. 12. 
ideologii antykomunistycznej. Przeciwstawiają się jej, wchodząc w interakcje wykorzystujące ramę, w której nie ma miejsca na ideologię".

„Polityka rzeczy małych” wytwarza więc przestrzeń dla autonomii. Jest sposobem egzystencji, który przedefiniowuje narzucone relacje. Można powiedzieć, że wytworzona przestrzeń publiczna jest przestrzenią bez interpelacji, podporządkowania władzy. To przestrzeń spotkań wolnych podmiotów, gdzie prawda nie łączy się z władzą. Goldfarb krytykuje Foucaulta za jego utożsamienie totalitaryzmu i liberalizmu. Uważa, że dużym brakiem koncepcji francuskiego filozofa jest niemożliwość normatywnej oceny na przykład systemu komunistycznego i postkomunistycznego. Ponadto, jest ono zbyt deterministyczne. Nie jest w stanie wyjaśnić niedomknięcia podporządkowania, wymywania się ideologiom. Goldfarb podaje przykład mediów, które unikają stania się tubami propagandowymi dzięki aktowości samych aktorów. Wypracowany przez wspólnotę etos, nakaz profesjonalizmu, chroni media przed przekształceniem się w kapitalistyczną wersję „Prawdy”.

Władzę rzeczy małych należy uwzględniać tak samo, jak uwzględnia się władzę rzeczy wielkich. ABC News nie jest być może instytucją zupełnie niezależną od finansowego rachunku w Disneyu, lecz gdy dziennikarze postępują jak dziennikarze i nawzajem monitorują swoje postępowanie, stwarzają dystans pomiędzy kwestią wyników finansowych i przekazywaniem wiadomości. Chomsky i inny chcieliby, abyśmy wierzyli, że między 'New York Times' i dawną 'Prawdą' istnieje niewielka różnica, lecz dzięki zaangażowaniu w niezależny profesjonalizm wypracowany w interakcjach przez profesjonalistów różnica ta jest w rzeczywistości wielka ${ }^{5}$.

Władza rzeczy małych ujawnia się również w przestrzeni edukacji. Uniwersytety czy szkoły są elementami szerszej struktury, mają pełnić określoną rolę. W pewnym sensie reguły gry w polu edukacyjnym są zdefiniowane i narzucone aktorom. Ponadto, istnieje tendencja do narzucania edukacji pozaedukacyjnych celów i znaczeń. Ujmowania jej albo jako produkcji politycznej albo rynkowej. Można powiedzieć, że jeżeli edukację analizujemy bez uwzględnienia „polityki małych rzeczy” dostrzegamy jedynie jej reprodukcyjny, podporządkowujący i podporządkowany charakter. Goldfarb odwołując się do własnych doświadczeń podkreśla „wywrotową" moc interakcji między aktorami. Spotkanie otwiera możliwość wprowadzania własnych reguł. To aktywność autorów umożliwia pojawienie się edukacji w przestrzeni szkolnej. Goldfarb pisze:

\footnotetext{
Ibidem, s. 39.

Ibidem, s. 11.
} 
Lektury i prace pisemne, obowiązkowe prezentacje ustne oraz aktywność na zajęciach tworzą organizacyjną ramę osadzoną w szerszym kontekście college'ów i uniwersytetów oraz winterakcjach między instytutami edukacji a resztą społeczeństwa. Ale to uczestnicy własnymi interakcjami definiują funkcjonowanie seminarium. Gdy profesor przychodzi z pożółkłymi notatkami i mechanicznie je odczytuje, usypiając w ten sposób studentów, to niezależnie od tego, jak znakomita jest uczelnia, a studenci i profesor - wspaniali, zajęcia kończą się fiaskiem. Moi studenci i ja podczas początkowych zajęć podjęliśmy trud zdefiniowania naszego seminarium jako rzeczywistego miejsca nauki, w którym będzie można wybierać alternatywne punkty widzenia i gdzie szanować się będzie zasadność i jakość argumentacji. A ponieważ zdefiniowaliśmy je w ten sposób, było to wiele bardziej prawdopodobne, że takie właśnie będzie ${ }^{6}$.

Definiowanie sytuacji przez demokratycznie zorganizowaną wspólnotę seminaryjną nie dotyczyło, zdaniem autora, jedynie powodzenia dydaktycznego pojedynczych zajęć. Walka toczyła się o znacznie ważniejszą kwestię, o samą edukację. Bez wysiłku podjętego przez aktorów, bez „polityki małych rzeczy", wydarzenie mogłoby się przekształcić w zwykły przekaz zasuszonej wiedzy albo w rynkowy czy ideologiczny trening.

Stawką nie były tylko jedne zajęcia w jednym college'u, ryzyko podejmowane przez jedną grupę studentów i profesora. Chodziło raczej o samą istotę wyższej edukacji. Od nas zależało rozstrzygnięcie najważniejszych kwestii w wojnach o kulturę, rozstrzygnięcie w sprawach relacji między polityką a edukacją, ogólnym i zawodowym wykształceniem, dyscypliną i autonomią ${ }^{7}$.

Autor sugeruje, że edukacja nie jest czymś danym. Czymś, nad czym czuwa państwo, instytucje edukacyjne ze sztabem menedżerów, biurokracji, szeregiem sposobów kontroli, nadzoru i dyscyplinowania. Nie uruchamia się jej automatycznie po wejściu do sali wykładowej. Jest czymś, co wymaga tworzenia, otwierania i wysiłku. Edukacja powstaje jako działalność autonomiczna uczących się, jako przestrzeń wyzwolona z logiki ogólnych struktur.

Warto zwrócić uwagę na to, jak Goldfarb rozumie edukację. Jego stanowisko nie jest w żaden sposób oryginalne. Wpasowuje się w ideologię edukacji liberalnej, którą oddziela od liberalizmu politycznego. Wychowanie liberalne jest wychowaniem przede wszystkim $\mathrm{w}$ demokracji, spotkaniem równych ludzi, którzy negocjują znaczenia przy wykorzystaniu narzędzi dopuszczonych w ramach zasad racjonalnej dyskusji. Rozmowa jest słowem kluczowym, mówi autor, rozmowa, podczas której każdy ma równe prawo głosu, gdzie nie zakłada się z góry przewidzianego rezultatu, ani nie blokuje się arbitralnie określonych perspektyw, pewnych światopoglądów czy interpretacji. W roz-

\footnotetext{
6 Ibidem, s. 112-113.

7 Ibidem, s. 113.
} 
mowie krzyżują się zróżnicowane perspektywy, nie aby rozpłynąć się w zakładanej jednorodności, ale przede wszystkim, aby pogłębić rozumienie tych różnic. W pewnym sensie tak pojęta edukacja jest miniprzestrzenią publiczną, formą polis, demokracją w praktyce. Edukacja przez autora jest rozumiana jako „wyjątkowy rodzaj swobodnej aktywności publicznej”.

Można powiedzieć, że powyżej przedstawiona wizja edukacji wiąże się w jakiś sposób z politycznym polem. To, co pedagogiczne, łączy się z tym, co polityczne. Wymiar polityczny edukacji jest często podkreślany. Pedagogika krytyczna wskazała, że pedagogika nie jest niewinną działalnością, czymś neutralnym. Dobór materiałów, metod, celów, jak i ogólny sposób rozumienia pola edukacyjnego ma wymiar polityczny.

Relacja między tym, co pedagogiczne a tym, co polityczne, może być ujmowana na różne sposoby. Różnica w konceptualizacji relacji między pedagogiką a polityką w znacznym stopniu zależy od konkretnego zdefiniowania członów relacji. Goldfarb, w rozumieniu polityki i edukacji, podąża tropem wyznaczonym przez Arendt, która w (nie)sławnym eseju pod tytułem KRYZYS EDUKACJI stwierdza, że edukacja musi zostać oddzielona od polityki, a polityka od edukacji. Przestrzeń szkolna powinna być wyraźnie wyodrębniona, stanowić raczej domowe schronienie, niż przestrzeń publiczną9. Swoisty azyl, gdzie nie-do-końca ludzie są pielęgnowani i wprowadzani w stary świat. Arendt stwierdza, że edukacja musi mieć charakter konserwatywny, zachowawczy.

[...] wydaje mi się, że konserwatyzm rozumiany jako zachowawczość, należy do istoty działalności edukacyjnej, której zadaniem zawsze jest pielęgnowanie i ochrona czegoś - dziecka przed światem, świata przed dzieckiem, nowego przed starym i starego przed nowym ${ }^{10}$.

Edukacja nie powinna, zdaniem Arendt, być skierowana w przyszłość. Nie należy traktować jej jako narzędzia do zamiany społecznej, motoru dla utopijnych wizji. Utopijne, polityczne wykorzystanie edukacji prowadzi do totalitaryzmu w stylu Platona. Ponadto, podporządkowanie polityce utopijnej, zmianie społecznej, tego, co pedagogiczne, sprawia, że to co nowe, związane z narodzinami jednostki, zostaje zaprzepaszczone. Edukacja przekształca się w indoktrynację.

8 Ibidem, s. 115 .

9 H. Arendt, Kryzys edukacji, [w:] eadem, Między czasem minionym a przyszłym. Osiem ćwiczeń z myśli politycznej, przekł. M. Gołdyń, W. Madej, Fundacja Aletheia, Warszawa 1994, s. 231.

$10 \quad$ Ibidem, s. 228. 
Rola jaką edukacja odgrywała we wszystkich utopiach politycznych od czasów starożytnych, pokazuje jak naturalne wydaje się rozpoczynanie nowego świata od tych, którzy są nowi z urodzenia i natury. Jeśli chodzi o politykę, kryje się tu oczywiście poważne nieporozumienie; zamiast dołączenia do równych sobie oraz podjęcia wysiłku perswazji i ryzyka niepowodzenia, mamy tu dyktatorską ingerencję opartą na absolutnej wyższości dorosłego i próbę wytworzenia nowego jako faktu dokonanego, to znaczy tak, jak gdyby to nowe już istniało. Dlatego też przekonanie, że jeśli chce się stworzyć nowe warunki, należy zacząć od dzieci, pozostało w Europie z reguły monopolem ruchów rewolucyjnych o orientacji despotycznej, które, kiedy dochodziły do władzy, odbierały dzieci rodzicom i po prostu poddawały je indoktrynacji ${ }^{11}$.

Nie tylko edukacja musi zostać oddzielona od polityki, ale również polityka od edukacji. Przeniesienie zasad edukacyjnych do świata polityki jest również wielkim nieporozumieniem. Tak, jak upolitycznienie edukacji prowadzi do jej kryzysu, tak uedukacyjnienie polityki wiąże się z utratą jej ducha.

Edukacja nie może odgrywać w polityce żadnej roli, ponieważ w sferze politycznej zawsze mamy do czynienia z tymi, którzy są już wychowani. Ktokolwiek zamierza wychowywać dorosłych, chce w istocie być ich kuratorem i nie dopuszczać ich do działalności politycznej ${ }^{12}$.

Zasady, w ramach których zorganizowana jest edukacja, z jej nierównością, hierarchią, konserwatyzmem, nie są zasadami, według których może funkcjonować polityka. Szkoła jest bliższa przestrzeni domowej, prywatnej, niż publicznej.

Goldfarb nie jest do końca wierny stanowisku Arendt. Wprawdzie podąża w znacznym stopniu jej śladem, podkreślając, że wykorzystanie edukacji do działania politycznego może przyczynić się jedynie do powstania tyranii, zastąpienia wolności i równości, podporządkowaniem i hierarchią, jak również sprzeciwia się ustalaniu relacji właściwych polityce w obszarze edukacji, to nie jest do końca wierny konserwatywnemu, hierarchicznemu modelowi. Edukacje ujmuje raczej jako przestrzeń publiczną niż prywatną - chociaż nie jest do końca w swojej narracji konsekwentny.

[...] zastąpienie relacji nauczyciel-uczeń relacją zastępującą występującą pomiędzy obywatelami również stanowi problem. Podważa wysiłek edukacyjny. Niegotowych do tego studentów trzeba dopiero przygotowywać do uczestnictwa w świecie. Pierwszym zadaniem nauczyciela wobec uczniów jest przedstawienie świata takiego, jakim go zna, by następnie mogli działać na tej podstawie, odwołując się przy tym do własnych opinii. Należy chronić ich przed presją bezpo-

11 Ibidem, s. 212.

12 Ibidem, s. 212-213. 
średnich problemów politycznych i ekonomicznymi troskami, aby mogli przygotować się do uczestniczenia w życiu publicznym jako dojrzali, odpowiedzialni, równi obywatele ${ }^{13}$.

Powyższy cytat sugeruje, że edukacja wymaga nierówności. Wydaje się, że Goldfarb powtarza założenia Arendt, która w przytaczanym wcześniej tekście, utrzymuje hierarchiczne zorganizowanie edukacji. Dziecko, nie jest jeszcze obywatelem, nie jest jeszcze pełnoprawnym członkiem społeczeństwa. „Przybysze ci nie są jeszcze ukształtowani, lecz dopiero stają się ludźmi”'14. Kulturowa, polityczna czy też rozumna niedojrzałość, nieludzkość istot stanowi legitymizację świadomie prowadzonej, opartej na autorytecie i hierarchii edukacji. Istnienie dzieci, uczniów, jako ludzi w sensie biologicznym, zostaje zepchnięte do sfery prywatnej, do mroków życia rodzinnego, gdzie znajduje ochronę. „W świecie publicznym, wspólnym wszystkim ludziom, liczą się osoby oraz dzieła naszych rąk, jakie każdy z nas wnosi na rzecz wspólnego świata; ale życie jako zwykłe istnienie nie ma tu znaczenia. Świat nie może się o nie troszczyć, a ono musi być ukryte i chronione przed światem"15. Dziecko, jako nie-człowiek, jest bytem tymczasowym. Dzieciństwo jest jedynie okresem przejściowym, którego, właściwości powinny zostać unicestwione. W ramach pedagogicznej refleksji Arendt widnieje jej klasyczne przeciwstawienie tego, co publiczne (męskie, dorosłe, obywatelskie, wolne, równe, dialogiczne), temu, co prywatne (kobiece, dziecięce, przedpolityczne, hierarchiczne, konieczne, milczące). Poza tym, pulsują w niej oświeceniowe nurty, które domagają się podporządkowania. Zdobycie dojrzałości, to nie tyle poddanie się rozumowi, ile utrata siebie dla abstrakcji ${ }^{16}$. Te dwa nurty pulsujące i nadające dynamikę myśleniu Arendt, sprawiają, że jej wizja demokracji i obywatelstwa jest co najmniej problematyczna ${ }^{17}$.

Wymóg nierówności wydaje się problematyczny nie tylko ogólnie, nie jedynie w ramach koncepcji Arendt (gdzie wewnętrznie jest logicznie uzasadniony), ale również w ramach struktury myśli Goldfarba. Wcześniej przytoczyłem fragment, w którym autor podkreśla wagę rozmowy, poszanowania dla innych opinii, ścierania się przeciwstawnych światopoglądów. Jeżeli

\footnotetext{
J. C. Goldfarb, Polityka rzeczy małych..., s. 114-115.

H. Arednt, Kryzys edukacji, s. 221.

Ibidem, s. 222.

${ }_{16}$ Zob. M. Stirner, Jedyny i jego własność, przekł. J. i A. Gajlewiczowie, PWN, Warszawa 1995.

${ }_{17}$ Zob. M. Bobako, Demokracja wobec różnicy. Multikulturalizm i feminizm w perspektywie polityki uznania, Wyd. Poznańskie, Poznań 2010; C. Pateman, Braterska umowa społeczna, przekł. K. Szumlewicz, biblioteka online Think Tanku Feministycznego, http://www. ekologiasztuka.pl/pdf/pateman.pdf [06.03.2014].
} 
edukacja ma stanowić próbę rozważania problemów w przestrzeni wolnej od narzuconej interpretacji, jeżeli aktywnością nauczyciela jest aktywowanie rozmowy, tworzenie atmosfery poszanowania inności, a poznawanie świata już samodzielnym działaniem ucznia, to dlaczego konieczna jest do tego nierówność?

Poza tym, pojawia się tutaj problem związany z uznaniem niedojrzałości uczniów. Nie są oni jeszcze obywatelami, a w takim razie należy z nich stworzyć obywateli. Czym taka produkcja różniłaby się od „totalitarnej” produkcji podmiotów? Niejasne jest również, jak z zasady nierówności i braku wolności może wyłonić się przestrzeń równości i wolności? Na obronę Goldfarba można wskazać, że przytoczony przez niego opis tego, co działo się na seminarium świadczy o niewierności koncepcji Arendt, którą, w pewnym stopniu, akceptuje na poziomie teoretycznym.

\begin{abstract}
Nie uważam jednak, by moja rola podczas zajęć polegała na przekonywaniu studentów do mojego stanowiska politycznego. Moim zdaniem jest raczej zachęcenie ich do uwzględnienia alternatywnych poglądów, natomiast do nich należy nauczenie się czegoś więcej o świecie, który zamieszkują i za który będą odpowiedzialni. To drobna, lecz ważna polityczna sprawa. Ten sposób postępowania miał na celu otwarcie przestrzeni dla edukacji. Miał doniosłe znaczenie polityczne, pomimo że nie wiązał się z żadnym konkretnym politycznym (stronniczym) stanowiskiem ${ }^{18}$.
\end{abstract}

Odrzucając stanowisko wypracowane przez pedagogikę krytyczną, Goldfarb stwierdza, że szkoła nie może być przestrzenią bitwy między lewicą i prawicą. Nie akceptuje również łączenia interesów, bieżących problemów z edukacją. Przeciwstawia się rozpraszaniu edukacji, wyprowadzaniu jej na „ulicę”. Sala szkolna czy wykładowa nie jest miejscem na „propagandę”. Należy powrócić do przestrzeni szkolnej wydzielonej z przestrzeni społecznej, opartej na czasie wolnym, aktywności niezwiązanej z biologicznym przetrwaniem, sferą brudnej pracy. Tak jak konkretnej polityki. Niemniej, edukacja jest polityczna w szerszym wymiarze, gdzie politykę rozumie się jako przestrzeń spotkań zróżnicowanej wielości dyskutującej o kształcie świata społecznego.

Wspomniałem już wcześniej, że żyjemy w czasie kryzysu. Demokracja jest nie tylko problematyczną kwestią filozoficzną, ale również praktyczną. Ruchy społeczne, tak samo jak filozofowie ${ }^{19}$, zakwestionowali panujący model. Wskazując na jego fasadowość globalna wielość zaczęła organi-

18 J. C. Goldfarb, Polityka rzeczy małych..., s. 113.

19 Zob. G. Agamben i in., Co dalej z demokracja, przekł. M. Kowalska, Instytut Wydawniczy Książka i Prasa, Warszawa 2012. 
zować się w inny sposób. Horyzontalizm, negacja wielkiej polityki, powrót do idei demokracji bezpośredniej stały się wyznacznikami nowych ruchów ${ }^{20}$. Goldfarb również zdaje się dostrzegać potęgę nowych ruchów społecznych. Niemniej, nie traktuje ich jako alternatywy dla panującego systemu, ale raczej jako narzędzie czy dopełnienie demokracji przedstawicielskiej. Internet jest rozumiany jako jedno z mediów, tak jak radio i telewizor, które zmieniają walkę o wyborców, które winny być wykorzystywane przez polityków, a nie jako inny sposób uprawiania polityki. Co ciekawe, u Goldfarba polityka małych rzeczy nieustannie przechodzi w wielką politykę. Nie stanowi samoistnej przestrzeni, która mogłaby zastąpić panujący model. Nie chodzi mi jedynie o podnoszoną przez autora kwestię mocy innych mediów jak telewizja, ale o samą strukturę polityki małych rzeczy. O ile jest ona bardziej opozycyjna w krajach totalitarnych, to w totalitaryzmie made in USA stanowi co najwyżej jego element. Interakcje nie tworzą autonomicznej przestrzeni wolności, ale są sterowane i waloryzowane przez zawodowych polityków. Można powiedzieć, że pod względem odwagi i utopijnego rozmachu, Goldfarb wlecze się za nowymi ruchami społecznymi, narzucając zmurszałą matrycę działania i interpretowania.

W tym miejscu warto wspomnieć na obronę Goldfarba, że dostrzega on prosytemowy charakter polityki rzeczy małych. Jak pisze: „Polityka rzeczy małych może równie dobrze wspierać status quo i dominujące tendencje, co stawiać im opór"21.

Okazuje się, że opowiadanie się za demokratyczną, oddolną organizacją nie określa politycznego charakteru ruchu. Polityka rzeczy małych może być wykorzystywana przez ruchy antydemokratyczne, fundamentalistyczne czy faszyzujące. Skrajna prawica wykorzystując praktyki i narracje antytotalitarne uruchamia machinę ustanawiania nowego totalitaryzmu, który wydaje się wolnościowy. Pojawia się problem, jak odróżnić totalitarną w konsekwencji politykę małych rzeczy od antytotalitarnej. Jest to pytanie, które nurtuje i przed którym stają teoretycy i praktycy radykalnej demokracji.

Odpowiedź udzielona przez Goldfarba jest oparta na rozróżnieniu prawdy filozoficznej i prawdy faktualnej. Problem ze skrajną prawicą polegałby na tym, że monopolizuje swoje stanowisko, własną opinię utożsamiając z prawdę i jednocześnie blokując inne sposoby narracji. Goldfarb stwierdza:

20 Zob. Sceny zokupowanej Ameryki, przekł. B. Szelewa, Warszawa 2012; M. Castels, Sieci oburzenia i nadziei. Ruchy społeczne w erze internetu, przekł. I. Siara, PWN, Warszawa 2013.

${ }_{21}$ J. C. Goldfarb, Polityka rzeczy matych..., s. 96. 
Opierając się na swych najbardziej podstawowych przekonaniach, ludzie formułują sądy dotyczące bieżących problemów i na ich podstawie działają w sferze publicznej. W pluralistycznym społeczeństwie bazującym na wielości przekonań mamy wciąż do czynienia ze swobodną wymianą alternatywnych opinii. Gdy jednak partykularne przekonania przedstawione są jako ostateczne rozstrzygnięcia kontrowersyjnych kwestii istotnych dla społeczeństwa, a ludzie działają, opierając się na prawdzie tych przekonań, by zyskać przewagę nad innymi, religia zastępuje swobodną polityczną interakcję 22 .

Inaczej mówiąc, dla skrajnej prawicy polityka rzeczy małych stanowi sposób organizowania zwolenników reprezentowanej przez nich Prawdy. Jest jedynie narzędziem, sposobem werbowania, nie zaś autonomiczną przestrzenią. To samo może dotyczyć również liberalnych polityków. Podział wydaje się rozchodzić między immanentną polityką, a zawłaszczaniem tej przestrzeni przez polityków zawodowych. Nie tyle spór rozgrywa się miedzy lewicą a prawicą, a między radykalną demokracją a formami demokracji przedstawicielskiej, między uczestnictwem a reprezentacją. Niemniej taki podział wymaga przeprowadzenia jeszcze jednej lini frontu - między pluralizmem a monizmem. Sam jednak pluralizm prowokuje wiele problemów. Przykładowo, może być on antagonistyczny, gdzie sprzeczności nie dotyczą jedynie stylów życia, a samego przetrwania. Taka jednak perspektywa wykracza poza pole teoretyczne, w którym pracuje Goldfarb.

Pomimo niektórych inspirujących uwag, praca Goldfarba wydaje się być powierzchowna i zmurszała.

Pole teoretyczne, jakie prezentuje, lokuje się na niskim poziomie teoretyczności. Brak problematyzacji podmiotu, mikropolityk władzy, interioryzacji i interpelacji, pozwala mu w prosty sposób krytykować Foucaulta. Również unikanie badania warunków możliwości własnego pola, pozwala na powtarzanie liberalnych sloganów. W pełni ignoruje materialne interesy i wynikające z nich sprzeczności, które determinują politykę i utrudniają wyłanianie się przestrzeni publicznej.

Goldfarb wydaje się zbytnio podkreślać moc definiowania sytuacji. Sugeruje jakoby wszystko zależało od aktorów. Powrócę do podanego przez niego przykładu seminarium. Oczywiste jest, że bez wysiłku definiowania, to, co się wydarzyło, by się nie wydarzyło. Niemniej, gdyby spróbował to samo uczynić w przeludnionym gimnazjum, czy nawet na prowincjonalnym uniwersytecie, w przeludnionej sali, jego możliwości definiowania byłyby, delikatnie mówiąc mocno ograniczone. Ponadto, skład klasowy studentów z seminarium Goldfarba sugeruje, że wprowadzone przez niego definiowanie

22 Ibidem, s. 106. 
odpowiadało stosunkowi do kultury reprezentowanym przez uczestników. Tu pojawia się kolejny problem, o którym wspomniałem wcześniej - redukcja polityki do dyskusji oraz jej indywidualistyczne ujmowanie. Nie ma w koncepcji Goldfarba miejsca dla zbiorowych akcji, masowych ruchów, klasowych wystąpień. Są jednostki, które się spotykają - tu według niego przebiega linia sporu.

Goldfarb nie odnosi się również do licznych, współczesnych koncepcji demokracji radykalnej. Wprowadzenie koncepcji infrapolityki, polityki mniejszościowej, czy politycznej postpolityki mogłoby wzbogacić wywód autora i uczynić go bardziej nowoczesnym. Uwzględnienie wspomnianych kategorii nie jest jedynie erudycyjnym zarzutem. Goldfarb ignoruje znaczną część głosów dobiegających z przestrzeni polityki rzeczy małych. Wymienione kategorie mogłyby mu pozwolić usłyszeć szepty, podziemne pieśni.

Goldfarb nie czuje nowych pieśni. Fałszuje na nutę antytotalitarną. Jego pieśń może, niestety, wciąż być atrakcyjna dla niektórych. Bo jest w niej coś, co warto wysłuchać. Opowieść o autonomicznym życiu, sile zwykłych ludzi. I oddolnym tworzeniu świata.

\section{BIBLIOGR AFIA}

Agamben G. i in., Co dalej z demokracją, przekł. M. Kowalska, Instytut Wydawniczy Książka i Prasa, Warszawa 2012.

Arendt H., Kryzys edukacji, [w:] eadem, Między czasem minionym a przyszłym. Osiem ćwiczeń z myśli politycznej, przekł. M. Gołdyń, W. Madej, Fundacja Aletheia, Warszawa 1994.

Bobako M., Demokracja wobec różnicy. Multikulturalizm i feminizm w perspektywie polityki uznania, Wyd. Poznańskie, Poznań 2010.

Castels M., Sieci oburzenia i nadziei. Ruchy społeczne w erze internetu, przekł. I. Siara, PWN, Warszawa 2013.

Goldfarb J. C., Polityka rzeczy małych. Siła bezsilnych w mrocznych czasach, przekł. U. Lisowska, K. Liszka, A. Orzechowski, DSW, Wrocław 2012.

Graeber D., Revolutions in Reverse: Essays on Politics, Violence, Art, and Imagination, Minor Compositions, Londyn - Nowy Jork - Port Watson 2011.

Pateman C., Braterska umowa społeczna, przekł. K. Szumlewicz, biblioteka online Think Tanku Feministycznego, http://www.ekologiasztuka.pl/pdf/pateman.pdf [06.03.2014].

Sceny z okupowanej Ameryki, przekł. B. Szelewa, Warszawa 2012.

Stirner M., Jedyny i jego własność, przekł. J. i A. Gajlewiczowie, PWN, Warszawa 1995.

\section{Small subversive politics}

\section{SUMMARY}

The text constitutes the review of the book The Politics of Small Things: The Power of the Powerless in Dark Times, written by Jeffrey C. Goldfarb. The author of the review reconstructs the understanding of the politics of small 
things, trying to answer such questions as: whether the theoretical Goldfarb's ideas are able to meet the current challenges, if they can be useful in the emancipatory struggle (also in the area of education), or perhaps they block it and retard?

KEYWORDS: the politics of small things, change, education. 